\title{
Indium In 111-CMD-193
}

National Cancer Institute

\section{Source}

National Cancer Institute. Indium In 111-CMD-193. NCI Thesaurus. Code C62481.

A radiolabeled antibody-targ eted antineoplastic antibiotic consisting of the enediyne antibiotic calicheamicin conjug ated with anti-Lewis $\mathrm{Y}$ antibody and labeled with indium In 111. In 111 CMD-193 binds to Lewis $Y$ antigen-expressing tumor cells via its antibody moiety and is internalized; subsequently, the calicheamicin moiety binds to the minor groove of tumor cell DNA, causing double-strand DNA breaks, the inhibition of DNA synthesis, and apoptosis. The indium In 111 radiolabel allows the detection of CMD-193 distribution and tumor localization using gamma scintigraphy. 